\title{
Lincoln in Brief: A Review Essay
}

\section{STACY PRATT MCDERMOTT}

Lincoln and the Union Governors, by William C. Harris. Concise Lincoln Library. Carbondale: Southern Illinois University Press, 2013. 163 pp. Illustrations, appendix, notes, bibliographical essay, index. $\$ 24.95$ hardcover and e-book.

Lincoln and the U.S. Colored Troops, by John David Smith. Concise Lincoln Library. Carbondale: Southern Illinois University Press, 2013. 156 pp. Notes, index. \$24.95 hardcover and e-book.

Lincoln's Campaign Biographies, by Thomas A. Horrocks. Concise Lincoln Library. Carbondale: Southern Illinois University Press, 2014. 148 pp. Illustrations, notes, bibliography, index. \$24.95 hardcover and e-book.

Lincoln and Religion, by Ferenc Morton Szasz with Margaret Connell Szasz. Concise Lincoln Library. Carbondale: Southern Illinois University Press, 2014. xviii, 103 pp. Illustrations, appendixes, bibliography, index. \$24.95 hardcover and e-book.

IN 2011, Southern Illinois University Press launched the Concise Lincoln Library, a series of short, focused books covering various topics on Abraham Lincoln. The purpose of the series is to offer students and lay readers approachable volumes that bring a fresh perspective to well-known topics and to provide a venue for examining previously overlooked areas of Lincoln's life. Wellknown Lincoln scholar Michael Burlingame provided one of the first volumes, Lincoln and the Civil War; ultimately, the press will publish more than 20 books in the series, covering such topics as

THE ANNALS OF IOWA 74 (Winter 2015). (C) The State Historical Society of Iowa, 2015. 
Lincoln's sense of humor, his assassination, the election of 1860, medicine, race, and Reconstruction. Most of the authors tapped to contribute to the series are well known to Lincoln scholars and voracious readers of books on Lincoln and the Civil War. As can be expected with any series, some books in the series overachieve, some hit the mark, and others are not quite up to the task. Given that enthusiasm for Lincoln seems never to abate and that his life still has the power to motivate and inspire us, the series makes a worthy contribution. Students and lay readers will find the short books to be good starting points for understanding Lincoln and the fascinating contexts of his era.

This review essay focuses on four of the books in the series, two published in 2013 and two in 2014, evaluating them individually on their own merits and providing a brief assessment of their overall contribution to Lincoln scholarship. The authors of all four of the books considered here are well-established scholars who published full-length monographs prior to their work for the Concise Lincoln Library. Three books cover topics that are not widely known or debated: campaign biographies, the role of Union governors in the Civil War, and the history of the U.S. Colored Troops. The fourth book, and by far the best of those reviewed here, offers a brief overview of a topic that Lincoln historians have widely written about and debated: religion.

In Lincoln and the U.S. Colored Troops, John David Smith, a prolific historian and editor, traces the use of black soldiers in the Civil War, examines the political and military purposes for their service, and details the hardships, inequalities, and racism black men suffered when they donned the uniform of a Union soldier. Smith covers the connections between emancipation and black military service, discusses the ways the U.S. Colored Troops changed the attitudes of many white soldiers and leaders who witnessed their abilities and bravery, and devotes several pages to the horrific attack at Fort Pillow, in which Confederates massacred some 200 black soldiers in April 1864. This volume would be a useful introduction for students investigating the Civil War and Reconstruction, African American studies, the history of race, or civil rights in the United States.

Smith's approach in this tidy volume reflects the excellent work of the scholars who contributed essays to a volume Smith 
edited in 2004 titled Black Soldiers in Blue: African American Troops in the Civil War Era. In fact, that book of essays in combination with Smith's succinct general narrative in Lincoln and the U.S. Colored Troops would provide students a broad understanding of this fascinating topic. At the end of his book, Smith offers readers some glimpses of how Abraham Lincoln's steps towards emancipation, particularly the use of black troops, "empowered African Americans and changed America" (115). In that final paragraph, Smith also suggests that Lincoln sparked a "revolution" with his policies, and "after another century of struggle, it finally allowed people of color to attain full American citizenship" (115). In the context of the shooting death of Michael Brown and the resulting riots in Ferguson, Missouri, in the summer and fall of 2014, midwestern students might view these concluding words of the book as a springboard for a lively discussion about the definition of revolution and the legacy of Abraham Lincoln and emancipation in American history.

Thomas A. Horrocks, director of the John Hay Library at Brown University, has long been interested in nineteenth-century media and its connections to American politics. In Lincoln's Campaign Biographies, he situates those political publications within the dramatic historical contexts of the 1860 and 1864 presidential campaigns, comparing and contrasting the constructed images of Lincoln and the public's response to them. Horrocks explains that honesty, integrity, and humility were characteristics that surfaced most prominently in campaign biographies of the era and that campaign biographies of Lincoln reflected that trend. Horrocks astutely recognizes that Lincoln understood the power of the written word as well as the power of photography; and that, as a politician, Lincoln expertly used the media and understood its importance to his political successes. Thus, the printed campaign biographies, with their deliberately evocative text and images of Lincoln, are valuable sources for historical analysis. As Horrocks correctly asserts, campaign biographies are "a lens through which scholars can examine what party leaders, commercial firms, the American reading public, and, in some cases, candidates, thought were essential qualities of character and leadership" and how nineteenth-century Americans "packaged and promoted these attributes" (73). 
Students familiar with the packaging of modern political candidates will find comparisons to the packaging of nineteenthcentury politicians fascinating. Some of the descriptions in Lincoln's Campaign Biographies will sound familiar; others will surprise. In that regard, the book is entertaining and useful. Yet while this volume focuses on an area of Lincoln studies that most historians have given only a cursory glance, it feels a bit stretched out into book length. A deeper analysis of a biography from each campaign, perhaps paired with an annotated transcription, might have made the book less like an academic article dressed up in a hardcover book. That small criticism aside, Horrocks offers students and lay readers a window into the relationship of public relations and politics in nineteenth-century America, a topic that will seem quite current to observers of the political spin so prevalent today.

Lincoln and the Union Governors, by noted Lincoln historian William C. Harris, brings to the fore the importance of northern state executives to Lincoln's war efforts. There is no new primary research in this volume-no systematic investigation of the papers of any of the 59 governors who served their states during the Civil War, for example. However, the book does provide a general understanding of Lincoln's relationships with governors. Harris pays particular attention to those governors who, basically, served as war ministers, including Oliver P. Morton of Indiana, Richard Yates of Illinois, and Samuel J. Kirkwood of Iowa. Likely, most students who have limited familiarity with the particulars of the Lincoln presidency and the American Civil War will know very little about the governors who oversaw Union army recruitment in their states. While Civil War historians have given border-state governors quite a bit of attention-Harris's own award-winning Lincoln and the Border States is a recent example-few books on the Civil War give much if any credit to governors in Union states like Indiana, Illinois, and Iowa.

In 1948, in Lincoln and the War Governors, William B. Hesseltine diminished the importance of the role of Northern governors, and historians have generally followed that interpretation. Harris argues that the war governors were at least as important in winning the war as were the generals who fought the battles. He also makes a compelling case that the gubernatorial conference 
at Altoona, Pennsylvania, in September 1862, was an example of the governors and Lincoln working together to end the war and to end slavery. Whereas Hesseltine and others have seen the Altoona event as insignificant, Harris devotes an entire chapter to the conference, contending that it provided an imperative morale boost to the governors and their constituents. Harris suggests that a full understanding of the Civil War is hindered by a focus that privileges the federal perspective over the perspective of the various Northern states, and his book makes clear the cooperation necessary for Union victory.

For Ferenc Morton Szasz, the Lincoln Concise Library series provided an opportunity to achieve a lifelong goal to publish a book on Lincoln and religion. An American cultural and social historian, Szasz was thrilled to finally begin that work, but a diagnosis of leukemia hindered his effort. Ultimately, the disease took his life before he could refine the manuscript. His wife, daughter, and son deciphered the draft that Szasz was able to complete, and the result is a wonderfully measured and thoughtful analysis of the historical contexts of Lincoln's personal perspectives on religion. Richard E. Etulain, one of the editors of the series for Southern Illinois University press and a close friend of Szasz, wrote a historiographical essay at the end of the book that is a useful complement to Szasz's narrative. The book offers an excellent and balanced introduction to the topic of Lincoln and religion for students and general readers.

Perhaps the book's most significant contribution is its expression of the centrality of religion to nineteenth-century Americans and the ways religious ideologies and rhetoric played a role in political discourse. For most students, this will be a new idea; and the knowledge that Abraham Lincoln arguably understood that connection better than most politicians and political observers of his era will open up a new dimension of Lincoln's famous words with which most students are already acquainted. As Szasz explains so succinctly, "during the Civil War era, politics, religion, and sacred language overlapped on a variety of fronts" (49). Students cannot fully understand Lincoln's famous speeches without first understanding this simple but often forgotten historical truth. Other historians - Allen Guelzo in Abraham Lincoln: Redeemer President and Ronald White in A. Lincoln: A Biography, 
for example-have analyzed Lincoln's religion in the context of the importance of religion in nineteenth-century American life. In this tidy volume, however, Szasz delicately avoids the temptation to appropriate Lincoln for one particular religious perspective or historical interpretation. The resulting narrative leaves readers in a position to interpret Lincoln's religion for themselves.

Overall, the authors of the volumes in the Concise Lincoln Library keep inquisitive students and lay readers in mind; the narratives of all four are engaging and easily accessible. Smith, Horrocks, and Harris offer excellent introductory chapters that lay out the historical contexts of their subjects for readers who may be new to the topics those books cover. Although Szasz's book lacks such an introduction, his summaries at the end of each chapter reflect his four decades of teaching and his ability to make historical material comprehensible to undergraduates. All but Smith's book offer either a useful bibliographical essay or a selected bibliography, which students will find useful for further investigation of the interesting topics within the volumes. At just over 100 pages of text each, the volumes are well suited for students as well for casual readers of history.

Undergraduate students and their professors in the Midwest, where Lincoln's resonance is particularly strong, will find most of the books in the series engaging and useful. Few of the books offer much in the way of new historical interpretation of Lincoln, but they do provide solid historical analysis. As well, and perhaps more importantly, students and lay readers alike will appreciate shorter treatments about diverse topics written by different historians with particular perspectives, approaches, and styles. Reading three or four books in the series along with a solid full-length biography of Lincoln would help students better understand the nuances of Lincoln's life and the complexities of the historical contexts in which he lived and worked. 